\title{
Hvorfor drar unge katolikker til World Youth Day?
}

\author{
Av Jane Skjoldli
}

Denne artikkelen utforsker bredden av motivasjonsfaktorer hos et utvalg respondenter som deltok $i$ World Youth Day (WYD) i Kraków, Polen. Tidligere forskning har etablert opplevelsen av religiøst fellesskap som det aspektet ved WYD-opplevelsen som gjør sterkest inntrykk for unge katolikker, men det har fătt mindre oppmerksomhet som en potensiell motivasjonsfaktor. Denne artikkelen nyanserer bildet ved å fokusere på selvrapporterte motivasjoner for deltakelse, og hvordan fellesskapsaspektet konstrueres $i$ intervjuer. Blant motivasjonsfaktorene finner vi transnasjonale møter, reisefellesskap, paver, helgener, hellige steder, en opplevelse av WYD-deltakelse som Guds vilje, men også arbeidsoppgaver og uvilje mot å delta. Artikkelen relaterer fellesskapsopplevelser til selvfortrylling og selvspiritualitet - konsepter som oftere appliseres $i$ studiet av nyreligiøsitet.

Nøkkelord: World Youth Day, WYD, verdensungdomsdagene. pave Frans, pave Johannes Paul II, helgener, hellige steder, pilegrimsferd, pilegrimsreise, religiøse fellesskap, religiøs motivasjon, religiøs deltakelse, stevne, festival, ungdom, ungdomskultur, katolisisme, Den katolske kirke, selvspiritualitet, selvfortrylling, selvrapportering, intervjuer, feltarbeid

JANE SKJoldLI. University of Bergen, Department of Archaeology, History, Cultural Studies and Religion (AHKR), Øysteins gate 3, 5020 Bergen.E-post: jane.skjoldli@uib.no

World Youth Day (WYD) er et religiøst stevne for ungdommer og unge voksne

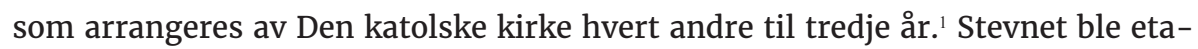
blert som en ny katolsk tradisjon i løpet av årene 1984-1986, men det var først i 1986 at stevnet fikk navnet World Youth Day. Aldersgruppen som er kvalifisert for å delta, strekker seg fra midten av tenårene til midten av trettiårene, med noe variasjon fra gang til gang; eksempelvis var aldersgrensene i 2016 satt til 16 og 36 år, mens de i 2008 var 15 og 35 (Mason, 2008: 2). I 2016 kom deltakerne fra 185 forskjellige land og tilbragte flere store fellessamlinger sammen, hvor faste poster på programmet er åpningsmesse, velkomstseremoni for paven, flerspråklig katekese, utøvelse av korsveien fredag, pilegrimsvandring til et

1 WYD ble feiret med større hyppighet under Pave Johannes Paul II (1978-2005) enn under Benedict XVI (2005-[2013]) og Frans (2013-).

Prismet - IKO-Forlaget 2017

Tilgjengelig på https://journals.uio.no/index.php/prismet Publisert under CC BY-NC 4.0. Fagfellevurdert 
samlingssted og nattevake lørdag, samt messefeiring søndag morgen. Vaken og søndagsmessen ledes alltid av paven. ${ }^{2}$

Dersom man tar utgangspunkt i promosjonsmateriale, dokumenter og medierapporter, som ofte fokuserer på paven, kan det være fristende å anta at paven er WYDs viktigste attraksjon og at møtet mellom paven og unge er det mest sentrale aspektet ved WYD. En slik antakelse gjør seg gjeldende hos religionssosiologene Alex Norman og Mark Johnson (2011), som riktignok observerer at katolske læremyndigheter, arrangører og journalister konsekvent kaller deltakerne for pilegrimer, stevnet for en pilegrimsferd, samt at paven er en sentral del av WYD som fenomen (Polish Press Agency and Catholic News Agency Poland, 2016). ${ }^{3}$ Deres fokus på paven som en flytende geografisk pilegrimsdestinasjon gjør det imidlertid vanskelig å se det som gjør WYD unikt sammenlignet med andre arrangementer $\mathrm{i}$ forbindelse med pavebes $\emptyset \mathrm{k}$ : at målgruppen utgjøres av ungdom og unge voksne og har et fastlagt program (Norman and Johnson 2011: 380). ${ }^{4}$ Ifølge eksisterende deltakerunders $\emptyset$ kelser er det imidlertid ikke paven som gjør størst inntrykk; det er heller opplevelsen av Den katolske kirke som et globalt religiøst fellesskap. Undersøkelsene vier imidlertid mindre oppmerksomhet til fellesskapsopplevelsers rolle som motivasjonsfaktor og hva fellesskapsopplevelsen går ut på (Mason, 2008: 6-8; Mason et al., 2008; Mason, 2009: 12-14). Spørsmålene som står sentralt i denne artikkelen er derfor: Hvorfor drar unge katolikker til WYD? I forlengelsen av det, hvordan kan vi forstå WYD-deltakeres fellesskapsopplevelse og rollen den spiller i deres motivasjoner for å delta? Hva kan det i sin tur fortelle om forståelsen av ungdom og fellesskap i katolsk kontekst?

\section{Metode og utvalg}

Hovedgrunnlaget for artikkelen er materiale samlet inn under feltarbeid, med semi-strukturerte intervjuer og ustrukturert deltakende observasjon som primærmetoder. Av et større utvalg er bare syv respondenter direkte synlige i denne artikkelen: seks kvinner og to menn, ett fullt medlem av en kvinnelig religiøs orden og seks lek-katolikker, men ingen ordinerte prester, diakoner, eller medlemmer av mannlige religiøse ordener inngår i det større utvalget, som også har en sterk overvekt av kvinnelige respondenter. Samtlige respondenter identifiserte seg som katolikker og oppgav å ha vokst opp i katolske hjem. Det var

2 Dette overgikk normalen, som ligger på 160-170 land (Jackowski et al., 2016).

3 Eksempelvis titulerte Vårt Lands journalist Heidi Marie Lindekleiv sin reportasje om WYD 2016 som «Festivalfarten», et ordspill på det norske begrepet valfart. Hun innlemmer også et sitat fra 21 år gamle Trai Paul Nguyen fra Stavanger, idet hun påpeker at «De heter forresten ikke deltakere: «Det er jo en pilegrimsreise vi er på» (Lindekleiv, 2016).

4 Også Sylvia Collins-Mayo ser ut til å ta for gitt at WYD er en pilegrimsferd, uten å spesifisere hva det innebærer (Collins-Mayo, 2012: 86). For en kritisk gjennomgang av stevnets utvikling og forholdet til pilegrim og pilegrimsferd som begreper, se (Skjoldli, 2017 [kommende]). 
en forutsetning for respondentrekruttering at kandidatene var fylt 18 år, noe som ekskluderte de yngste WYD-deltakerne. To respondenter var i sine sene tenår, fire i tjueårene, og to i trettiårene. I materialet for denne artikkelen inngår to gruppeintervjuer og to individuelle intervjuer. Som ledd i anonymiseringsprosessen er respondentene tildelt alias, delt inn i aldersgrupper fremfor å bli gjengitt med eksakt alder, og potensielt identifiserende informasjon om reisegruppen og bispedømmet som var ansvarlig for den, er fjernet eller endret.

Alle respondentene $\mathrm{i}$ artikkelen er fra samme reisegruppe. Første kontakt med respondentutvalget ble etablert under et opphold som gjesteforsker ved det katolske University of Notre Dame i USA våren 2015. Da fikk jeg kontakt med katolikker fra flere steder i landet, herunder en gruppe unge voksne katolikker som tilhørte et bispedømme med planer om å dra til WYD 2016 i Kraków, Polen. Etter å ha informert gruppelederen om forskningsprosjektet, inviterte han meg til å reise sammen med dem. Det konkrete utvalget ble gjort under feltopphold i Polen, ved personlig kontakt med hver enkelt respondent. I Polen dro jeg sammen med reisegruppen fra Warszawa til Częstochowa, Katowice, Wadowice, og Auschwitz II: Birkenau før vi ankom Kraków hvor selve WYD-arrangementet fant sted. De forutgående stoppestedene stod på en lang liste over «steder av interesse» i Polen for WYD-deltakere og ble omtalt som stoppesteder på en lengre pilegrimsferd. ${ }^{5}$ Reisen varte i totalt ti dager.

I denne artikkelen fokuserer jeg på respondentenes selvrapporterte motivasjoner for å delta i WYD 2016 og supplerer med observasjoner. Intervjuer er problematiske kilder til religiøs praksis, men også til motivasjonsfaktorer fordi selvrapportering ikke tegner rene, fullstendige, eller reelle bilder (Stausberg, 2011b: 383-384). Likevel kan man anta at selvrapporterte motivasjoner utgjør en del av respondentenes selvforståelse som deltakere og er med på å konstruere deres personlige WYD-narrativ. Materialet kan derfor fortelle noe om hva deltakerne $\emptyset$ nsker å kommunisere om seg selv, om sin deltakelse, og om arrangementet. Konstruksjon av personlige narrativ er også viktig for sosiale prosesser hvorved normative idealer konstrueres og opprettholdes, ved å signalisere hvilke motivasjonsfaktorer som har høyere og lavere status. Det indikerer ikke mangel på oppriktighet, men kan signalisere forestillinger om hva oppriktighet er og hvilke føringer slike forestillinger legger for hva som er og ikke er sosialt akseptabel motivasjon for å delta på WYD. Samtlige intervjusitater er oversatt fra engelsk. Alle oversettelser er mine egne og har innebåret noen milde omformuleringer for å ivareta meningsinnhold på idiomatisk nivå.

\footnotetext{
5 Lesere som er interesserte i forhold mellom religion og turisme kan finne det interessant at Polens offisielle turistorganisasjon samarbeidet med WYD på dette området. Eksempelvis lenker den offisielle arrangementssiden for WYD 2016 direkte til turistorganisasjonens nettsider, noe som hinter til det symbiotiske forholdet mellom WYD som katolsk arrangement og vertslandets turistindustri (WYD Krakow 2016, 2016).
} 


\section{Motivasjonsfaktorer}

\section{High five med katolikker fra hele verden}

En varm og solfylt morgen utenfor konsert- og konferansesenteret Tauron Arena intervjuet jeg en gruppe med fire kvinnelige deltakere i tjueårene. Ett av de første spørsmålene gjaldt hvorfor respondentene bestemte seg for å delta. Aria, en kvinne i tjueårene, grep ordet:

Jeg bare: «Jeg elsker å reise, jeg elsker troen min.» Liksom «Hva ... hva mer er det å finne ut om dette [stevnet]? Meld meg på!» Så jeg ble bare veldig fascinert av det faktum at det er folk fra verden rundt som møtes.

Victoria, - en annen kvinne i tjueårene - nikket et bekreftende «mhm», før hun fulgte opp:

Ja. Jeg tror det er greien for meg. [...] Jeg liker å oppleve hvor global og universell Kirken er. Liksom: Du kan se flagg fra alle land, [gjøre] high five [med] katolikker fra hele verden. Liksom: Hva søren er det, liksom, hvorfor skulle vi få muligheten til å gjøre dette?

Aria fulgte opp med en anekdote: «Folk fra Australia stod ved siden av meg da vi var på Messe i Częstochowa og det var bare ... ett av de mest meningsfylte øyeblikkene så langt.» Jeg bad henne utdype:

Bare det å innse at, liksom, «Hei, vi [feirer] denne messen. Biskop [navn] sier messen, men deres biskop er også der oppe [ved alteret], men vi svarer liksom alle på samme måte. Vi deler alle den [samme] troen. Vi [etablerer] alle en dyp forbindelse med det stedet og vår tro - alle på samme tid.» Og det var bare veldig, ehm, dypt på den måten at det var: «Wow, dette er ... Dette er virkelig det vi dro hit for.»

Jeg spurte dem hva de likte med fellesskapsopplevelsen og hvordan det var forskjellig hjemme og på WYD. Aria fortsatte:

Vanligvis - hjemme, hvis jeg er ute et sted, ehm ... Noen ganger er det flotte samtaler, du har vennlige diskusjoner med folk, men det er hele tiden som om du er på ballen, liksom [...] Som hvis du har en venn fra en eller annen protestantisk religion, som er kristen liksom men ikke katolikk, som stiller alle disse spørsmålene og du må vœre i stand til å besvare dem ... Det er på en måte fint å bare ikke ha det stresset. [...] Liksom, alle her, vi tror liksom alle på det samme og vi kan alle bare tilbe sammen her og nå.

6 Victoria bruker ikke noen spesifiserende adjektiver sammen med «kirken» (the church), noe som tyder på at hun snakker om Kirken med stor K - ekklesia som Kristi kropp. Ideen om at Den katolske kirken utgjør et sentrum for en bredere, allmenn Kirke med stor K som brer seg utover institusjonens grenser, er gammel, men ble i moderne tid dominerende under og etter Andre Vatikankonsil. Den franske dominikanermunken Yves Congars ekklesiologi hadde betydelig innflytelse i denne retningen (Dulles, 2002: 41). 
«Det er som om du kjenner sjelen deres litt allerede», sa Victoria, før Aria la til: «Det er liksom når du finner ut at «Åja, du er katolikk. OK.» Det er det bonding-øyeblikket; dette kommer til å fungere. Dette kommer til å gå helt fint. Liksom at «Du forstår meg»! » lo hun. ${ }^{7}$

Sophia, også hun i tjueårene, meldte seg nå inn i samtalen. Inspirert av Victorias svar tidligere, la hun til at man «får en idé om hvor universelt det [fellesskapet] er.» Jeg spurte hvorfor universalitet er viktig for henne.

Fordi jeg vet liksom, $i$ hvert fall for meg personlig, at det er veldig lett a bli fanget $i$ det hverdagslige med troen din, ikke sant? Og bare, du blir liksom fanget $i, d u$ vet, bare ditt eget [lokale] fellesskap - som er vakkert, men hvis vi skal være, du vet, en universell kirke, synes jeg det liksom er viktig å forstå det konseptet litt bedre. Og derfor liksom, tror jeg for meg, var det å vare i stand til å komme og bare oppleve det mer håndfast - eller se det tydeligere - veldig viktig. Og det bare gir deg et større perspektiv på hva du er en del av.

Når respondentene forklarer hvorfor fellesskapsopplevelsen er viktig for dem, sammenligner de sine lokale fellesskap hjemme i USA med WYD, hvor de opplever Kirken som et universelt, transnasjonalt, og implisitt globalt, fellesskap. Man oppfatter også at fellesskapsopplevelsen er moro for dem gjennom konkrete, uformelle uttrykk som å hilse på grupper fra andre land i gatene, hvor de klasker nevene med hverandre mens de passerer, men også i mer formelle sammenhenger, hvor fellesskapet får uttrykk gjennom lik respons i messeliturgien. For Aria var det et uttrykk for «samme tro», noe hun opplevde som befriende på et sosialt nivå. Det var imidlertid ikke bare det globale fellesskapet som ble styrket.

\section{Reisefellesskapet}

Adelaide er en nonne i de tidlig trettiårene og hadde allerede deltatt ved WYD 2011 i Madrid. Tidligere hadde hun utpekt fellesskap som ett av de viktigste aspektene ved å være katolikk for henne. WYD gav fellesskapet i bispedømmet et særskilt uttrykk, forklarte hun: « Jeg synes bare det føles lettere og mer sammensatt [communified] her, siden vi er alle samlet og vi er så nærme, så vi kan gå [til fots] overalt. Det er virkelig fantastisk.»

Det var ikke tilfeldig at hun knyttet fellesskapsopplevelsen til det å gå sammen til fots. Før hvert arrangement som involverte hele reisegruppen, samlet vi oss for å gå sammen til de ulike stedene. Samlingens funksjon var nok primært logistisk og organisatorisk; det gjorde det lettere for reiselederne å holde oversikt over alle deltakerne i reisegruppen, samt for deltakerne å trygt nå frem til hver enkelt destinasjon. Samtidig tilrettela samlingene for felles religiøs

7 Opplevelsen av å ha religiøst fellesskap med andre på egen alder som en motsetning til hverdagslige situasjoner, har også fellestrekk med kristne stevner i Norge (Trysnes, 2013: 32). 
praksis, ofte gjennom bønn (særlig av Rosenkransen og Den guddommelige barmhjertighets krans) og en humoristisk sang som uttrykte reisegruppens tilhørighet til et felles bispedømme under felles biskop. ${ }^{8}$ Den biskopen som alle WYD-deltakere har felles, er biskopen av Roma - paven.

\section{Paver, helgener og pilegrimsferd}

Flere forskere har vært opptatt av å se på paven som motivasjonsfaktor, og her er det lett å anta at det er den regjerende paven som er viktigst. Materialet mitt maler imidlertid et mer nyansert bilde. Ibis, som jeg intervjuet individuelt, forklarte at hun ønsket å være med for å få «åndelig fornyelse», samt at hun mente WYD-turen « ville være en flott måte å besøke et annet land på»; da kunne hun kombinere utenlandsbes $\emptyset \mathrm{k}$ med å gå til messe hver dag og «bes $\emptyset$ ke disse hellige stedene».

Om jeg ser, liksom, paven, ikke sant, tenkte jeg: «Hey, det ville være et pluss! tror ikke min hovedgrunn for å komme er å se paven, men å se katolikker fra hele verden. Og bare å kunne ha flere påfølgende dager der du bare, liksom, er fylt av bønn og, du vet, sånne ting.

Ibis trodde imidlertid at paven var en hovedattraksjon for andre deltakere: «Ja, jeg kjenner folk som bare: «Jeg skal endelig få se paven!» og jeg bare, «Vel, det er mange folk her! » lo hun. Ibis hadde imidlertid allerede sett paven dagen før, da han passerte henne og en annen deltaker.

Samme dag stod vi i lobbyen til hotellet og ventet på at vi skulle dra. Plutselig spredte det seg et rykte om at paven snart skulle passere gaten utenfor i bil, på grunn av en politibilkaravane som passerte. De fleste av dem som var samlet, løp ut av lobbyen for å se ham kjøre forbi. Skuffelsen var merkbar da det ble oppdaget at det ikke var Frans, og alle som var kommet ut, somlet seg inn igjen i lobbyen. Det kunne virke som om Ibis ikke opplevde det å se paven som en tilstrekkelig god nok motivasjonsfaktor og stilte dermed opp andre faktorer $\mathrm{i}$ tillegg - faktorer som peker mot mer normativt aksepterte religiøse objekter som messefeiring, helgener og helligsteder.

Det var imidlertid en annen pave som det lot til å være langt større aksept for å fremheve som motivasjonsfaktor. Dette kom først på bordet da Victoria løftet frem besøk til hellige steder.

Du vet konseptet om, liksom, en pilegrimsferd som liksom en helliggjørende opplevelse; du vet: reisingen og det å vœre på hellige steder hvor du ikke ville hatt sjansen til å være og å be på steder hvor du ikke ville hatt sjansen til å be. Jeg tror det er en annen grunn til at jeg kom.

8 Det er dessverre ikke mulig å gjengi sangteksten uten å gå på kompromiss med anonymiseringsløftet og dermed bryte forskningsetiske retningslinjer. 


\section{Sophia la til:}

Det er liksom, å vœre på de samme - fordi du vet, ehm - vi holder disse helgenene så høyt fordi de er en så god rollemodell [sic]. [...] Så alle disse kanoniserte helgenene som alle snakker om, ikke sant, å vœre en førsterangs rollemodell, og hvordan det er meningen at vi på en måte imiterer deres [leve]måte. Og, liksom bare å vœre på samme sted hvor de var, er bare ... Det gjør det bare så mye mer ...

«... virkelig», skjøt Victoria inn. «Virkelig, ja!» svarte Sophia. Man kan dermed spørre hva «det» var som ble så mye mer virkelig. Før, under og etter bes $\emptyset$ kene til de hellige stedene tilknyttet Johannes Paul II, vektla reisegruppelederne og særlig prestene ulike sider ved hans semihagiografiske biografi - da særlig hans hengivenhet til Jomfru Maria. ${ }^{9}$ Man kan dermed tenke seg at det var de hagiografiske, narrative elementene ved Johannes Paul II som ble mer virkelig for dem.

Jeg spurte gruppen hvilke helgener som var viktigst for dem på denne reisen. «Definitivt JP2,» svarte Victoria, som dermed brukte den populære forkortelsen for Johannes Paul II. Hun la også til at Edith Stein - en jødisk kvinne som konverterte til katolisismen og ble nonne - var viktig for henne, særlig under besøket til Auschwitz. «'Hvilket gasskammer,' ikke sant 'ble hun sendt til' og 'hvor stod hun'.» Victorias forhold til denne spesifikke helgenen gav dermed besøket et nytt lag av mening. Auschwitz var ikke bare et sted med sterk historisk relevans eller generell religiøs interesse; det var et sted hvor hun selv fikk leve seg inn i livet til en helgen som var personlig viktig for henne. Andre helgener som var viktige for dem, var nonnen Faustina Kowalska - opphavskvinnen til Jesus-bildet Den guddommelige barmhjertighet - samt Maximilian Kolbe, som regnes for martyr da han tilbød seg å dø i stedet for en annen i Auschwitz (Johnson and Zurlo, 2014: 679). ${ }^{10}$

Johannes Paul II bes $\varnothing$ kte også Auschwitz i 1979, og dødsleiren stod på bes $\emptyset \mathrm{ks-}$ listen til pave Frans. Som pave i 26 år strakk førstnevntes pontifikat seg langt inn i livene til mange av deltakerne. Nettopp dette understrekte Aria idet hun spekulerte i at: «Jeg tror JP2 er viktig for alle oss som kommer hit fordi, ikke sant, det var han som var pave fra tiden da vi ble født og frem til tiden da vi ble, liksom, unge voksne.» Hun la til:

Det er bare det at han som er den vi alltid har hørt om og bare, ikke sant, å vite at dette er [stedet] hvor hans tro ble formet og dette er, ikke sant, han kjempet så mye for ehm,

9 Johannes Paul II ble populært dyrket som helgen før han ble helgenkåret, særlig etter saligkåringen i 2011 (Skjoldli, 2012). Han ble helgenkåret sammen med Johannes XXIII i 2014. Biografier om Johannes Paul II inneholder ofte semihagiografiske elementer. De er semihagiografiske fordi de hinter til hagiografiske aspekter ved hans liv heller enn å eksplisitt etablere dem. Et godt eksempel på dette er George Weigels to bestselgende biografiske verker (Weigel, 2005 (2001); Weigel, 2010). Han regnes også som en av skytshelgenene for WYD generelt, og WYD 2016 spesielt.

10 I Auschwitz var det særlig Kolbe som ble fremhevet, blant annet gjennom en stor plansje som var satt opp utenfor brakken hvor han ble holdt fanget. Her stilte flere av deltakerne seg opp for å be inntil brakkeveggen. 
troen i sitt eget land. Og han elsket det så høyt og han ble pave og ble slik en stor leder. [...] En rollemodell for oss alle [...] Det tar veldig pusten fra en å være, liksom, overalt hvor han har vært, på en måte.

Johannes Paul II og besøk til stedene hvor han hadde vært, var viktig for Aria på samme måte som Edith Stein var viktig for Victoria. Bes $\emptyset \mathrm{k}$ til steder tilknyttet deres livshistorie gjorde åpenbart sterkt inntrykk på dem. Her kommer også helgenpaven frem som forbilde. I et ytterligere eksempel fra senere i intervjuet, spurte jeg gruppen hva de trodde paven håper på å oppnå gjennom WYD: «Denne paven eller JP2?» spurte Aria. Altså, «paven» som var så viktig for Victoria og Sophia, var ikke Frans, men Johannes Paul II, og fordi han var den de kjente som pave under sin oppvekst, var det ikke gitt hvilken pave man snakket om ved bruk av ordet paven.

Selv om Johannes Paul II var viktig for dem personlig og formet grunnlaget for reisen som en pilegrimsferd i den forstand at det innebærer besøk til hellige steder, hadde pave Frans også betydelig appell. Sophia sa hun «tenker at World Youth Day passer for pave Frans» og utdypet:

Jeg tenker bare at han har denne gleden, ikke sant - alle snakker om hvor glad han er.

Han bare har denne gleden og denne freden og dette, dette håpet, og han vet hvordan han skal forene folk, tror jeg. Og det er det World Youth Day handler om - enhet og, du vet, bare glede og håp og derfor, ehm, tenker jeg at jo mer han kan levendegjøre det $i$ Kirken, scerlig i de unge [...] vil det bli oppnådd; hele ideen om World Youth Day vil bli oppnådd.

For Sophia var det enhet, glede og håp pave Frans kunne oppnå gjennom WYD; det er dette hun anser som arrangementets formål og essens. Det er også verd å legge merke til hennes tro på at det hun identifiserer som målet med WYD vil bli oppnådd. Pave Frans kroppsliggjør med andre ord formålet med WYD ved sine egenskaper. Victoria beskriver WYD som en pilegrimsferd, noe som gir synlighet til noe langt mer dyptgripende. Som tidligere nevnt påpeker Norman og Johnson at begrepene pilegrim og pilegrimsferd gjennomsyrer hele arrangementet (2011: 378).

\section{Tvetydig motivasjon}

To av respondentene gav imidlertid uttrykk for at deres motivasjon ikke var entydig. Det betydde imidlertid ikke at det var ensidig mundane motivasjonsfaktorer som drev dem til WYD 2016. «For meg er det en del av jobben min,» lo Caspar:

Men om jeg ikke ville dra, er jeg ikke sikker på at jeg ville blitt tvunget til å dra heller, så ... Ja. Jeg vet ikke. [...] Det som var spesielt med denne var Polen, som - jeg har aldri vart 
i Polen før og det var JP2s hjemland. Og med pave - scrlig pave Frans - ehm, jeg ville gjerne ha det her borte med pave Frans. Høre hva han har å si. Så det var en kombinasjon av ting. [...] Fordi jeg er eldre, husker jeg JP2 mer enn pilegrimene her også, så det er en sterkere kobling for meg.

For Caspar var de selvrapporterte motivasjonsfaktorene altså knyttet til arbeid, Johannes Paul II og pave Frans. Hans primære motivasjon var altså ikke religiøst, men heller pragmatisk orientert. Caspar fant sin kontrast i Oliver, som leende uttrykte at «ehm, helt ærlig: Jeg ville ikke dra.» «Hvorfor ikke?» spurte jeg.

Fordi jeg visste hva jeg involverte meg i. Jeg er ikke noen fan av folkemengder. Og ehm, jeg er [i slutten av trettiårene], så jeg begynner å bli litt eldre. Liksom, jeg - jeg har barn hjemme som jeg kommer til å savne og ehm, så det var bare en av de tingene hvor [...] «Jeg lar ungene dra. De kan ha det gøy.» Ehm. Men nei, jeg satt i kirken og følte meg på en måte bare kallet. Jeg hadde denne følelsen, liksom, at jeg liksom burde dra. Og hvis vi skal få gode bilder av dette stevnet, ehm ... Jeg kjenner egentlig ingen andre som kan påta seg det. [...] Så her er jeg!

Jeg fikk inntrykk av at Oliver kjente på dårlig samvittighet overfor det å etterlate ektefelle og barn i ti dager. Han gav også uttrykk for å føle seg litt utilpass fordi han var litt eldre enn de andre i reisegruppen. Jeg grov litt: «Så derfor bestemte du deg for å dra, du følte at Gud ville at du skulle være her, på en måte?»

Nettopp. Og jeg utviklet det bittelitt på en måte, hvor ehm... Som da jeg dro [til WYD $i$ Köln] i 2005, var det ikke velorganisert fra - vår private reise var ikke så godt organisert. Det var mye mer som en ferie, mindre som en pilegrimsferd. Så vi hadde denne fine turpakken med fine hotell og $\ll \AA$, forresten, vi skal til World Youth Day [...] mot slutten av uken», skjønner du? Så vi hadde en fin tid i Tyskland, ikke sant, på tur til alle disse forskjellige stedene og sånn, men det var også veldig lett å på en måte bare, åndelig sett cruise gjennom arrangementet og ikke virkelig grave seg ned i det. Så mitt mål med kameraet mitt er [...] å få dem - i alle fall i et øyeblikk - til å stoppe og bare komme ut av seg selv.

Oliver deltok først på WYD som elev ved high school. «Jeg var en dust», lo han. Jeg var som en hvilken som helst annen videregående-gutt. Jeg og vennene mine var, eh, jeg mener vi - vi spilte hacky sack mens de [andre] gjorde Korsstasjonene. Skjønner du? Vi liksom bare [drev og] tøyset. Til lunsj gikk vi på Hooters - som er en restaurant hvor jenter går med upassende klær - fordi vi var high-school-gutter, ikke sant. Det er ikke meg nå i det hele tatt, men meg på den tiden - det var meg. Så du skulle tro at å dra til dette svœre arrangementet midt i Denver var meningsløst for meg. Men det var det ikke! [...] Jeg så for første gang den universelle katolske kirken. Du vet, ordet «katolsk» betyr 
«universell», så å se den verdensvide katolske kirken åpnet virkelig øynene mine.

Når Oliver beskriver sin tidligere WYD-opplevelse fra 2005 i Köln som dårlig organisert, med fine hotell, mer som en ferie og mindre som en pilegrimsferd, kommer vi også nærmere behovet for en guddommelig inspirert motivasjon for å kunne rettferdiggjøre egen deltakelse.

Olivers følelse av at Gud ville ha ham med på WYD, tillot ham å sette egen deltakelse inn i en ny ramme: Han etterlot ikke familien for å dra på ferie til Europa med en rekke unge voksne; han skulle utføre en guddommelig gitt oppgave som innebar å hjelpe ungdommer til å oppnå den samme fellesskapsopplevelsen som han beskrev som definerende for sin egen religiøse utvikling. Her kommer det også frem et uttrykk for et skille mellom ulike motivasjonsfaktorers status; Oliver $\emptyset$ nsket å gjøre det som kanskje var en «ferie» for yngre deltakere, til en pilegrimsferd. Han søkte å innlemme dem i samme opplevelse som han selv hadde hatt.

\section{Distansering til et yngre selv}

I sammenheng med den sosiale konstruksjonen av ulik sosial status for forskjellige motivasjonsfaktorer finner vi skiller mellom et tidligere, yngre jeg og et nåværende, eldre ungt jeg.

I likhet med Søster Adelaide og Victoria hadde også Oliver og Caspar deltatt ved tidligere WYD-stevner. WYD 2016 var de to sistnevntes tredje stevne: Oliver hadde tidligere vært i Denver i 1993 og Köln i 2005, mens Caspar hadde vært i Köln i 2005 og Madrid i 2011. WYD 1993 gav Oliver et nytt perspektiv på kirken hans, som han fortalte at motiverte ham til å lære mer om katolisisme. Et tydelig før/etter-skille som markerer seg i Olivers narrativ som har paralleller til Benedict Andersons konversjonsdefinisjon (Anderson 2006 [1983]: 15). Definisjonen er ikke basert på «aksept av særskilte religiøse læresetninger, men alkymisk absorbering ». Riktignok innebærer Andersons definisjon at man bytter ut én identitet med ett navn med en annen identitet knyttet til et annet navn. Det passer ikke umiddelbart her da Oliver definerer seg selv som både «krybbekatolikk»" og «hedning» på den tiden, men Andersons poeng er likevel aktuelt: «Hele naturen til menneskets væren er sakralt formbart». I Olivers tilfelle er det nettopp opplevelsen av å se universalitet - å se det større, globale fellesskapet som gjorde så sterkt inntrykk på ham at det formet hans identitet som katolikk, noe som kan minne om andre eksempler på opplevelser av seg selv om en del av «noe st $ø$ rre» (James 1985 [1902]: 361; Chemin 2012: vi). Han var født inn i en katolsk familie og beholdt en katolsk identitet, men betrakter likevel sin tidligere adferd og holdninger som «hedenske». Oliver og Caspar var eldre enn de andre

11 «rybbekatolikk» (cradle Catholic) er et begrep som brukes om katolikker som ble døpt som barn og oppdratt som katolikk, som regel i en katolsk familie. 
respondentene, noe som kan være med på å forklare deres tvetydige motivasjon for å delta i et ungdomsstevne, men deres minner om tidligere WYD-erfaringer forteller likevel noe om hvordan motivasjon for WYD-deltakelse kan utvikle seg i senere livsfaser.

Sammen med Olivers vitnesbyrd er Victorias fremstilling av WYD 2005 i Köln av interesse:

Jeg var veldig ung på den tiden, så jeg tenkte mye mer på det som en ferie. [...] Jeg var bare ikke mentalt $i$ stand til å oppleve det som en pilegrimsferd, tror jeg. Jeg har noen nøkkelminner, som å gå til Messe på tysk og bare liksom «Det er det samme! Alle delene [av liturgien] er de samme! 》 Og jeg vet i grunn hva som skjer og bare liksom « $\AA$, det er kult. Katolsk er virkelig universelt, liksom. Fett.» Det er i grunnen det hele. $\AA$, og mange folkemengder. Mange folkemengder [ler.]

Jeg spurte henne hva hun opplevde som forskjellig mellom Köln 2005 og Kraków 2016.

Vel, jeg er mye eldre nå, så jeg mener det er nesten - mer enn ti år siden at jeg dro dit, så jeg er bare mye sunnere åndelig, liksom. Jeg vet hvorfor jeg er katolikk nå, og liksom hvor jeg er i mitt åndelige liv er mye mer klart for en opplevelse som dette. Jeg [har] også mye mindre energi, så det er en enorm utfordring å komme seg rundt og det føles mer pilegrimsferdaktig [pilgrimage-y].

Victoria skiller mellom sin deltakelse ved WYD 2005 og 2016 ved å kontrastere holdninger og kapasitet for pilegrimsferd, og det hun kaller «åndelig sunnhet», hvori hun legger bevissthet rundt egen religiøs identitet. I motsetning til oliver gir ikke Victoria noe spesifikt narrativt konversjonspunkt. Hos begge ser man en kontrasterende distansering mellom ens tidligere jeg: et yngre, mindre katolsk, mindre informert, mindre seriøst jeg; et jeg man har vokst fra, ikke lenger identifiserer seg med, og som behandler det som skal være en pilegrimsferd som en ferie, og dermed bryter med normer og idealer man senere har internalisert. Det nåværende jeg er annerledes: Det er et eldre, mer katolsk, mer informert jeg; et jeg man har vokst inn i, stolt identifiserer seg med, og som behandler det som kunne vært en ferie som en pilegrimsferd.

Både Oliver og Victoria făr også frem at man skiller mellom ulike måter å tilnærme seg WYD på. Skillet går ikke her mellom begrepene turisme og pilegrimsferd - turisme kan godt involvere ønsker om å se et annet land og oppleve dets historie og kultur. Disse faktorene er både vel integrert og viktige idealer blant respondentene. I stedet går skillet mellom begrepene ferie og pilegrimsferd, hvor ferie implisitt indikerer gøy og avslapning preget av manglende religiøs interesse, og hvordan et yngre jeg mangler enten interesse eller kapasitet for å behandle WYD som en pilegrimsferd. Fra disse respondentene å dømme, handler 
det å behandle WYD som pilegrimsferd om å være bevisst sin religiøse identitet og hvorfor man er katolikk, vise interesse for helgener, aktuelle helligsteder, messedeltakelse og andre religiøse hengivenhets $\emptyset$ velser. ${ }^{12}$

Oliver og Victoria legemliggjør WYD-suksessnarrativer, hvor stevnet har bidratt til å $\emptyset \mathrm{ke}$ to unge katolikkers religiøse engasjement. Her er det verd å nevne at WYD skiller seg fra øvrige kristne stevner i samme deltakerskala, som for eksempel karismatiske misjonsmøter hvor konvertering av ikke-kristne er et sentralt mål. ${ }^{13}$ WYD er nemlig et ledd i det som kalles Den nye evangeliseringen, og har først og fremst til hensikt å evangelisere unge som allerede er medlemmer av Den katolske kirke. ${ }^{14}$ Med andre ord: WYDs målgruppe er ikke så mye ikke-katolikker som katolikker med lav interesse og det magisteriet gjerne kaller lavt nivå av internalisert katekese; slik sett kan man betrakte WYD som en form for intrakatolsk indremisjon. WYDs formål overfor målgruppen er også en spesifikk form for konversjon, nemlig fra mindre til mer engasjert. Slik sett passer særlig Olivers opplevelse inn i Michael Masons unders $\emptyset$ kelse av konversjon ved WYD, fra et «nominelt medlemskap til mer hengivent engasjement; eller fra en mindre opplevelsesrettet form for religiøsitet til en mer intenst affektiv form» (Mason 2010: 3). Olivers konversjon skriver seg dermed inn i Masons konversjonsmodell og da særlig en type konversjon som inntreffer på grunn av sosialisering, «fra utsiden og inn», hvor tilhørighet kommer først og påfølges av «personlig tro» (Mason 2010: 7-8).

Et annet perspektiv som her støtter Masons tidligere forskning, er WYD som overgangsrituale med endret adferd, inkludert overgangen fra svakere til sterkere engasjement blant unge. Et slikt perspektiv er særlig aktuelt med tanke på hvordan respondentene skiller mellom sitt tidligere, yngre jeg og sitt nåværende jeg. I denne sammenhengen blir beskrivelsen av seg selv som «yngre da» både en forklaringsmodell for tidligere (mis)forståelse av WYD, samtidig som den tjener til å unnskylde de yngre deltakerne, som man implisitt identifiserte som litt mer ferierende og litt mindre «pilegrimsaktige». Her trakk Victoria frem lavere energinivå tilknyttet høyere alder som noe som økte ubehag og dermed bidro til å gi WYD et mer pilegrimsaktig preg for henne.

\footnotetext{
12 Det er nok mer konvensjonelt å snakke om fromhetsøvelser, men jeg bruker hengivenhetsøvelse her av to grunner. Først fordi det får bedre frem det relasjonelle aspektet mellom utøver og Gud eller helgen, et poeng Håkon Tandberg etterlyser større oppmerksomhet for blant religionsvitere (Tandberg, 2013), og dernest fordi det er en bedre oversettelse av innsidebegrepet som brukes om denne formen for religiøse øvelser, nemlig devotion(al) $s$.

13 Se for eksempel (Cox, 1995: 221) Det finnes eksisterende forskning på konvertitter ved WYD, men kriteriet for å vurdere en respondent som konvertitt er svært romslig og skiller ikke mellom respondenter med og uten katolsk bakgrunn (Mason, 2010: 12).

14 Selv om han ofte får æren for det, var det ikke Johannes Paul II som gav navnet til Den nye evangeliseringen. Han definerte imidlertid målsetningen for prosjektet som «å gjenoppdage og gjenopplive den kristne tradisjon og kultur», med utgangspunkt i Den katolske kirken i latin-amerikanske land (Johannes Paul II, 1986: Nr. 1).
} 


\section{Et mangfold av motivasjonsfaktorer i skjæringsfeltet mellom individ og fellesskap}

Respondentene peker på flere motivasjoner. Aria liker å reise, men ble også fascinert av det globale aspektet ved arrangementet, i likhet med Victoria, som også impliserte at det var et stort privilegium for henne å be på hellige steder. For Sophia var det viktig å oppleve noe annet enn det hverdagslige fellesskapet hjemme. Søster Adelaide satte stor pris på det å kunne gå til alle destinasjonene til fots. Ibis var opptatt av «åndelig fornyelse» og ville gjerne se paven, men vektla også møter med andre mennesker. Oliver og Caspar uttrykte mer blandede motivasjonsfaktorer.

Irene Trysnes har påpekt at det gjerne er lavere terskel for å delta i stevnesammenheng enn det er å krysse dørterskelen inn til et religiøst møte (2013: 31). Foruten utgiften det er for mange deltakere å reise til stevnestedet, kan man spekulere i om ikke det samme kan ofte sies om WYD. Andre forskere har foreslått en typologi med fire forskjellige kategorier deltakere: Hengivne, Involverte, Åpne og Sosiale, hvor de to siste kategoriene til sammen ble anslătt å utgjøre halvparten av deltakerne - omtrent en fjerdedel hver - som igjen peker på at WYD kan ha lavere terskel enn mange andre former for katolske ungdomstilbud (Mason 2008: 2). Ruth Webber har foreslått at «gøy » og «store folkemengder» er blant elementene ved WYD som kan være tiltrekkende på unge (Webber, 2008: 2). Her er det verd å merke seg at Oliver ikke liker folkemengder. Det hadde han til felles med flere andre i reisegruppen, som ofte forklarte sin misnøye overfor folkemengdene med at de var innadvendte (introvert), mens de andre var utadvendte (extrovert). Det konstruerte et skille mellom de som likte og ikke likte å være i folkemengder. Webbers forslag om at folkemengder virker tiltrekkende på ungdom, behøver derfor nyansering overfor WYD-deltakere. På den annen side inviterer det også til nyansering av Abby Days argument, at religion blant ungdommer primært tegner et bilde av små fellesskap; selv om små fellesskap også er viktige ved WYD, bidrar også hvert enkelt individ, tilhørende sine relativt små fellesskap, til et langt større, globalt fellesskap (2009: 268-269).

\section{Motivasjonsfaktorer har forskjellig status}

De forskjellige motivasjonsfaktorene har ulik status blant respondentene. Opplevelsen av Den katolske kirkes universalitet handler ikke om å få et globalt perspektiv, men om å få bekreftet et eksisterende globalt perspektiv ved å oppleve en tilstrekkelig overbevisende representasjon av det. Flagg fra hele verden i store folkemengder som utøver samme liturgiske manuskript, materialiserer en selvopplevelse som del av et fellesskap som ikke bare er «større enn seg selv», men som overgår ens egen fatteevne. Slik sett kan opplevelsen av enhet $i$ ulikhet og et forenende, transnasjonalt fellesskap forstås som en form 
for selvglobalisering (Callero 2008: 1983). ${ }^{15}$

Reiselyst og nysgjerrighet overfor et annet land er også fremtredende. Det indikerer at deltakerne ikke hadde motforestillinger mot å rapportere turismerelatert motivasjon. De markerte imidlertid sterk avstand mot en holdning til WYD som «bare ferie». Med andre ord ble ikke turisme ansett som en dårlig og slett ikke tabubelagt motivasjonsfaktor, så lenge den hadde et religiøst preg; turisme var akseptabelt så lenge det hadde et religiøst fortegn..$^{16}$

Hvilke motivasjonsfaktorer man ilegger andre og markerer avstand fra, gir indikasjoner på hvilke som betraktes å være av høyere eller lavere status. Eksempelvis hadde $\emptyset$ nsker om å se den regjerende paven lavere status enn motivasjonsfaktorer knyttet til Johannes Paul II, som ble helgenkåret i 2014. Når respondentene uttrykker større entusiasme for Johannes Paul II enn Frans, behøver det ikke nødvendigvis skyldes at de har et nærere forhold til ham. Det kan også skyldes at Johannes Paul II står høyere i kurs blant konservative katolikker enn Frans, som gjerne fremstilles som mer «liberal» enn sine to forgjengere. Det hører også til at den til enhver tid regjerende paven har høy kjendisfaktor, noe som kan gjøre katolikker som tilhører konservative sokn og bispedømmer særlig sårbare for kritikk. ${ }^{17}$ Dette er særlig gjeldende i amerikansk kontekst, hvor protestantiske anklager om pavedyrkelse og spørsmål ved katolikkers lojalitet hang i lenger enn i Europa. ${ }^{18}$ Samtidig var det ikke entydig hvilken pave det dreide seg om når respondentene fikk spørsmål om paven. Det kan tyde på at også bildet av paven som motivasjonsfaktor for WYD behøver noen grad av nyansering. På den annen side var WYD 2016 spesiell i dette henseende, i og med at Kraków og Polen har så mange steder knyttet til Johannes Paul IIs biografi som i kraft av hans helgenstatus utgjør potensielle pilegrimsdestinasjoner.

\section{Fellesskapsspiritualitet og selvspiritualitet}

Blant alle de ulike motivasjonsfaktorene står fellesskapsopplevelsen sentralt: For Aria kom det best frem under en internasjonal engelskspråklig messe i Częstochowa, foran ikonet av Vår Frue av Jasna Góra - ett av Polens viktigste helligsteder. Sophia stiller opp en kontrast mellom det lokale religiøse fellesskapet og en bevissthet om et bredere, globalt fellesskap, mens Adelaide opplevde at det lokale fellesskapet representert av reisegruppen ble mer sammenknyttet enn hjemme. Sophia viste også til hvordan fellesskapsopplevelsen handlet om å få

\footnotetext{
15 Det er imidlertid problematisk å følge hans resonnement videre, da han bruker religiøs «fundamentalisme» som eksempel på reaksjon på globalisering.

16 For en innføring i religiøs turisme som analytisk kategori, se (Stausberg, 2011a).

17 Fremstillingen av Johannes Paul II er problematisk i et historisk perspektiv. Eksempelvis ble spørsmålet om hvorvidt han selv var liberal, diskutert i en nyhetsartikkel i avisen Gazeta Wyborcza i 1997 (Ernest, 1997).

18 I USA, mer enn i mange andre land, har katolikker måttet tilpasse seg en minoritetstilværelse i en majoritetskultur sterkt styrt av protestantisk hegemoni. Dette ble særlig tydelig under valgkampen før John F. Kennedy ble president (McGreevy, 1997: 130). Se også (Jenkins, 2003; Tweed, 2011).
} 
et annet perspektiv på sin egen plass i Den katolske kirke som en global religiøs st $\varnothing$ rrelse.

I Imagined Communities bruker Benedict Anderson konseptet forestilte fellesskap i en antropologisk analyse av nasjoner som sosialt konstruerte størrelser. Flere forskere har imidlertid benyttet konseptet for å belyse forestilte fellesskap i religiøse kontekster, også i møte med Den katolske kirke (Ryall, 2001). Konseptet kan også belyse WYD som en innfallsvinkel til «Den universelle katolske kirken» som forestilt fellesskap. Konseptet er særlig relevant i WYD-sammenheng da Anderson forstår forestilte fellesskap som fellesskap hvor «medlemmene [...] aldri vil komme til å kjenne de fleste av sine med-medlemmer, møte dem, eller selv høre om dem, men i hvert enkelt [medlems] sinn lever bildet av deres fellesskap» (Anderson 2006 [1983]: 5). WYD-deltakere møter heller ikke de fleste av de andre deltakerne, langt mindre alle verdens katolikker. Likevel er hver enkelt deltaker med på å forme bildet av et enormt, transnasjonalt fellesskap. I kraft av de mange flaggene og det høye deltakerantallet blir WYD et bilde på Den katolske kirke i sin helhet.

I Ritual Criticism siterer Ronald Grimes en katolikk blant sine respondenter: «[Liturgien] er veldig kjent og blir lett ignorert. [Det er] aldri [slik at] alle gjør alt sammen. Vi må på en måte gjøre dette fordi hvis vi ikke gjør det, er vi ikke» (Grimes 2010: 25). Fellesskapsopplevelsen er heller ikke bare visuelt fundert; allsang, high fives og synkron rituell respons rotfester fellesskapsopplevelsen også i audiell og taktil kultur - altså materiell kultur i bredere forstand. De ulike materiellkulturelle aspektene refererer altså tilbake til respondentene selv som deltakere og deres opplevelse av å være én del av en større helhet. Fellesskapsopplevelsen er med andre ord forankret i et materielt ut $\emptyset$ vende selv. Fellesskapsopplevelsen ved WYD tilbyr altså en ny religiøs selvforståelse med det enorme, transnasjonale stevnefellesskapet som middel og inngangsport. Det inviterer til å snu perspektivet fra å anse WYD som en fellesskapsspiritualitet forankret i individet, til også å forstå WYD som selvspiritualitet forankret i fellesskapsutøvelse; det forestilte globale fellesskapet er uløselig knyttet til det forestilte selvet som en del av et forestilt fellesskap. Med andre ord kan man identifisere selvglobalisering som en sentral funksjon ved WYD.

Dersom WYD-deltakeres selvforståelse forankres, medieres og globaliseres gjennom møtet med og utøvelse av et transnasjonalt fellesskap, og ikles et religiøst fellesskapsspråk, kan det skjule disse aspektene på overflaten. Fellesskapsspråket både tilslører og avdekker at opplevelsen av fellesskap også er en opplevelse av seg selv som en del av noe større. På den ene siden tilsløres det i en språkdrakt som fremhever fellesskapsord som Kirken og universalitet, samt at opplevelsen kommer til uttrykk i møter med andre mennesker som tilhører samme fellesskap som en selv. På den andre siden avdekkes det samme ved at 
referansepunktene stadig er respondentenes egne opplevelser og møter.

Dette har paralleller til det forskere på nyreligiøsitetsfeltet har kalt «selvdyrkelse» (cult of the self), en form for selvspiritualitet med røtter i moderne individualisme og terapeutisering (Burchardt, 2017). Her skal man imidlertid ikke trekke parallellene langt før man oppdager at de skiller seg ad, og en sterkere parallell kommer frem til en form for selvfortrylling. Selvfortryllingen er individualistisk forankret, samtidig som den stiger frem av fellesskapet, og kan skrives inn i et bredere vestlig refortryllingsnarrativ, her med kristent fortegn (Gilhus, 2014: 9). Fellesskapet får selv en form for selvtranscendens. ${ }^{19}$

Broen mellom ungdomskultur og katolisisme får dermed et selvspirituelt og selvfortryllende fellesskapelig uttrykk. En slik vinkling vil man i prinsippet kunne anklage for vestosentrisme, siden utvalget her utelukkende består av amerikanske WYD-deltakere. Det handler om å endre rammene for ens egen religiøse identitet.

\section{KonkLuSJON}

I epilogen til andre utgave av Sylvia Collins-Mayo og Pink Dandelions Religion and Youth, skriver Linda Woodhead at det «ikke lenger nytter å snakke om «ungdom» eller «ungdomskultur» på en udifferensiert måte»; religion spiller ulik rolle for forskjellige ungdommer i ulike kontekster (Woodhead, 2016: 239). I denne artikkelen har vi sett eksempler på det. Vi har sett at det å tilhøre forskjellige aldersgrupper kan utgjøre «ulike kontekster» i WYD-sammenheng, samt at ulike motivasjonsfaktorer kan betraktes som mer eller mindre religi$\emptyset$ se, men inngår i et mer helhetlig og nyansert bilde av hva som motiverer unge katolikker til å delta. Ved å unders $\emptyset$ ke selvrapporterte motivasjoner for å delta ved WYD 2016, fremtrer et komplekst bilde av reiselyst, paver, helgener, helligsteder, og en følelse av Guds kall, men også ulyst og plikt. Mest gjennomgående er imidlertid et $\emptyset$ nske om å møte andre katolikker - ikke først og fremst enkeltvis, men i en stor mengde og dermed gjennom en transnasjonal fellesskapsopplevelse, et funn som her st $\emptyset$ tter tidligere funn publisert av andre forskere. For noen av respondentene som fremtrer i denne artikkelen, har fellesskapsopplevelsen gjort et så sterkt inntrykk at de skiller mellom et «før» og et «etter» deres første WYD-opplevelse.

Dykker vi dypere ned i hva fellesskapsopplevelsen betyr for den enkelte, ser vi at den er materielt forankret og har selvspirituelle og selvfortryllende trekk, og kan bidra til å styrke unge katolikkers engasjement ved å omdefinere deres forståelse av sin plass i et større religiøst fellesskap. Dersom den enkelte deltaker

19 Selvspiritualiteten er nemlig også koblet sammen med prestehierarkiet, læremyndighetene, og de mest sentrale sakramentene de råder over som utgjør kriterier for katolsk fellesskapsforankring: skriftemål og kommunion. Normativt sett er skriftemål i katolsk sammenheng en forutsetning for kommunionsdeltakelse dersom man har gjort seg skyldig i en dødssynd. 
bidrar til å gjøre det transnasjonale fellesskapet til hva det er, kan fellesskapsopplevelsen ved WYD også endre deltakernes selvoppfatning. Det er med andre ord et dialektisk forhold mellom enkeltdeltakeren og fellesskapet som bidrar til å forme begge, og styrke religiøs identitet og fellesskapstilhørighet integrert i et transnasjonalt globalt perspektiv. I et globalt perspektiv tjener WYD dermed til å integrere ungdomskultur som et adskilt sjikt i en større, transnasjonal helhet og enhet.

\section{LITTERATUR}

Anderson, Benedict. 2006 [1983]. Imagined Communities: Reflections on the Origin and Spread of Nationalism. London: Verso.

Callero, Peter L. 2008. «The Globalization of Self: Role and Identity: Transformation from Above and Below.» Sociology Compass. Vol. 2, s. 1972-1988.

Chemin, Eduardo. 2012. Pilgrimage in a Secular Age: Religious \& Consumer Landscapes of Late-Modernity. Department of Sociology. Berlin: University of Exeter.

Collins-Mayo, Sylvia. 2012. «Youth and Religion: An international perspective.» Theo-Web. Zeitschrift für Religionspädagogik. Vol. 11, s. 80-94.

Cox, Harvey. 1995. Fire From Heaven: The Rise of Pentecostal Spirituality and the Reshaping of Religion in the Twenty-First Century. Cambridge, Da Capo Press.

Day, Abby. 2009. «Believing in belonging: An ethnography of young people's constructions of belief.» Culture and Religion. Vol. 10, s. 263-278.

Dulles, Avery. 2002. Models of the Church. New York: Random House.

Ernest, Skalski. 1997. «Czy Jan Paweł II jest liberałem?» Gazeta Wyborcza. 16. aug. 1997, s. 15.

Gilhus, Ingvild S. 2014. «Medialisering og refortrylling: Religiøs endring i Norge.» Din: Tidsskrift for religion og kultur. Nr. 1, s. 9-26.

Grimes, Ronald L. 2010. Ritual Criticism: Case Studies in Its Practice, Essays on Its Theory. Oxford, Oxford University Press.

Jackowski, Antoni, et al. 2016. «World Youth Day in Kraków in the light of experiences from around the world.» Det jagellonske universitet. Tilgjengelig: https://www. researchgate.net/profile/Elzbieta_Bilska-Wodecka/publication/305496990_ World_Youth_Day_in_Krakow_in_the_light_of_experiences_from_around_ the_world/links/57d41ae908ae601b39a8a4c3.pdf [29. mars 2017].

James, William. 1985 [1902]. The Varieties of Religious Experience. London: Penguin Classics.

Jenkins, Philip. 2003. The New Anti-Catholicism: The Last Acceptable Prejudice. Oxford: Oxford University Press.

John Paul II, Pope. 1986. Message of His Holiness John Paul II to Youth of the World on the Occasion of the II World Youth Day 1987. 30. nov. 1986. Tilgjengelig: http:// w2.vatican.va/content/john-paul-ii/en/messages/youth/documents/hf_jp-ii_ 
mes_30111986_ii-world-youth-day.html. [10. aug. 2016].

Johnson, Todd M. \& Zurlo, Gina A. 2014. «Christian Martyrdom as a Pervasive Phenomenon.» Society. Vol. 51, s. 679-685.

Lindekleiv, Heidi Marie. 2016. «Festivalfarten.» Vårt Land. 29. juli 2016. http://www. vl.no/reportasjer/reportasje/festivalfarten-1.759075. [26. feb. 2017.]

Mason, Michael. 2008. «World Youth Day 2008 Outcomes for Pilgrims.» Annual Meeting of the Society for the Scientific Study of Religion, Louisville, KY, okt. 2008.

Mason, Michael. 2009. «The Underlying Dynamics of World Youth Day.» Annual Meeting of the Society for the Scientific Study of Religion 2009, Denver. A14, okt. 2009.

Mason, Michael. 2010. «Converts at World Youth Day.» Annual Meeting of the Association for the Sociology of Religion, Atlanta, GA. Panel G2.

Mason, Michael, Webber, Ruth \& Singleton, Andrew. 2008. «Media Release 14/8/08 Survey of World Youth Day pilgrims finds out who went and why.» Tilgjengelig: http://dlibrary.acu.edu.au/research/wyd/UPDATES/summary/summary.html. [1. sept. 2015.]

McGreevy, John T. 1997. «Thinking on One's Own: Catholicism in the American Intellectual Imagination, 1928-1960.» The Journal of American History. Vol. 84, s. 97-131.

Norman, Alex \& Johnson, Mark. 2011. «World Youth Day: the creation of a modern pilgrimage event for evangelical intent. » Journal of Contemporary Religion. Vol. 26, s. 371-385.

Polish Press Agency \& Catholic News Agency Poland. 2016. «Around 2 million people from 185 countries to attend WYD in Poland. $>$ Pope in Poland 2016 Press Center. 6. sept. 2016. Tilgjengelig: http://www.pope2016.com/en/wyd-2016/about-wyd/ news,478431, around-2-million-people-from-185-countries-to-attend-wydin-poland.html [18. feb. 2017].

Ryall, David. 2001. «The Catholic Church as a Transnational Actor.» Josselin, Daphné \& Wallace, William (red.) Non-State Actors in World Politics. London: Palgrave Macmillan, s. 41-58.

Skjoldli, Jane. 2012. Nærvœr i fravœr: Materiell kommunikasjon om og med pave Johannes Paul II i Roma. Institutt for arkeologi, historie, kultur- og religionsvitenskap. Mastergradoppgave. Gilhus, Ingvild S. (veil.). BORA, Universitetet i Bergen.

Skjoldli, Jane. 2017 [kommende]. World Youth Day: Religious interface and immersion at a Catholic pilgrimage for young people. Institutt for arkeologi, historie, kultur- og religionsvitenskap. Mastergradoppgave. Stausberg, Michael; Tweed, Thomas A. (veil.). Universitetet i Bergen.

Stausberg, Michael. 2011a. Religion and Tourism: Crossroads, Destinations and Encounters. Oxon: Routledge. 
Stausberg, Michael. 2011b. «Structured Observation.» Stausberg, Michael \& Engler, Steven (red.) The Routledge Handbook of Research Methods in the Study of Religion. London: Routledge, s. 382-394.

Tandberg, Håkon. 2013. «Symbol er eld er gud: eit portrettintervju med Håkon Tandberg. » Halsnes, Magnus (red.) Ph.D-portrett. Universitetet i Bergen, Institutt for arkeologi, historie, kultur- og religionsvitenskap. Tilgjengelig: http://www. uib.no/ahkr/31246/symbol-er-eld-er-gud-eit-portrettintervju-med-håkontandberg [29. mars 2017].

Trysnes, Irene. 2013. «Religiøse festivaler og festivalreligion.» Prismet. Vol. 64, s. 31-44.

Tweed, Thomas A. 2011. America's Church: The National Shrine and Catholic Presence in the Nation's Capital. New York: Oxford University Press.

Webber, Ruth. 2008. «The social milieu of World Youth Day 08 and Pilgrims' social ethics.» Annual Meeting of the Society for the Scientific Study of Religion, Louisville KY, okt. 2008.

Weigel, George. 2005 (2001). Witness to Hope: The Biography of Pope John Paul II. New York: Harper Perennial.

Weigel, George. 2010. The End and the Beginning: Pope John Paul II: The Victory of Freedom, the Last Years, the Legacy. New York: Doubleday.

Woodhead, Linda. 2016. «Epilogue.» Collins-Mayo, Sylvia \& Dandelion, Pink (red.) Religion and Youth. 2. utgave. Oxon: Routledge.

WYD Krakow 2016. 2016. «Discover Poland.» Tilgjengelig: https://www.poland. travel/en/cities-\&-towns-9. [7. feb. 2017]. 